\title{
PENYESUAIAN DIRI ANAK ASUH DI LEMBAGA KESEJAHTERAAN SOSIAL ANAK (LKSA)
}

\author{
Youri Alkayyis \\ Politeknik Kesejahteraan Sosial Bandung, youri.alkayyis171@gmail.com \\ Dwi Yuliani \\ Politeknik Kesejahteraan Sosial Bandung,dwi_stks@yahoo.co.id \\ Windriyati \\ Politeknik Kesejahteraan Sosial Bandung, windrystks@gmail.com
}

\begin{abstract}
Self-adjustment refers to the suitability of individual behavior, so that there is a harmonious relationship between themselves and the environment. This study aims to obtain an empirical picture of: 1) characteristics of foster children, 2) adaptation of foster children to the natural environment, 3) adaptation of foster children to the social environment, 4) adaptation of foster children to themselves, and 5) the adaptation of foster children to the tensions, conflicts and frustrations they experience at the Child Welfare Institution (CWI). The method used in this research is secondary data analysis. The number of respondents was 417 foster children with the age ranges between 6-21 years in the following six locations: 1) Bina Remaja Taruna Jaya Social Institution in South Jakarta, 2) XVII Youth Inabah Pondok Putri Suryalaya Islamic Boarding School in Ciamis, 3) Putra Putra Primary 5 Children's Orphanage in East Jakarta, 4) The Muhammadiyah Orphanage in Klaten, 5) Marsudi Putra Antasena Social Home in Magelang, and 6) Baiturahmah Orphanage in Kampar, Riau. Data analysis techniques used are the reduction and categorization of data, organizing data, and interpretation. The results showed that the adaptation of foster children to the natural environment showed a high category, adjustment to the social environment shows a low category because there are still many foster children who do not have a good relationship with other foster children, coaches and employees/staff, adjustment to themselves shows a low category because foster children find it difficult to control emotions and cannot focus on participating in activities at the Child Welfare Institution (CWI), adjusting to the tension, conflict and frustration they experienced showed a moderate category.
\end{abstract}

Keywords:

Self-Adjustment, Foster child, Child Welfare Institution

\begin{abstract}
Abstrak
Penyesuaian diri merujuk pada kesesuaian perilaku individu, agar terjalin hubungan yang harmonis antara dirinya dengan lingkungan. Penelitian ini bertujuan untuk memperoleh gambaran secara empiris tentang: 1) karakteristik anak asuh, 2) penyesuaian diri anak asuh terhadap lingkungan alamiah, 3) penyesuaian diri anak asuh terhadap lingkungan sosial, 4) penyesuaian diri anak asuh terhadap diri sendiri, dan 5) penyesuaian diri anak asuh terhadap ketegangan, konflik dan frustasi yang dialaminya di Lembaga Kesejahteraan Sosial Anak (LKSA). Metode yang digunakan dalam penelitian ini adalah analisis data sekunder. Jumlah responden sebanyak 417 anak asuh yang terdiri dari usia 6-21 tahun di enam lokasi berikut: 1) Panti Sosial Bina Remaja Taruna Jaya di Jakarta Selatan, 2) Pondok Remaja Inabah XVII Puteri Pesantren Suryalaya di Ciamis, 3) Panti Sosial Asuhan Anak (PSAA) Putra Utama 5 di Jakarta Timur, 4) Panti Asuhan Yatim Piatu Muhammadiyah di Klaten, 5) Panti Sosial Marsudi Putra Antasena di Magelang, dan 6) Panti Asuhan Baiturahmah di Kampar, Riau. Teknik pengumpulan data yang digunakan adalah analisis data sekunder. Teknik analisis data yang digunakan adalah reduksi dan kategorisasi data, mengorganisasikan data, serta interpretasi. Hasil penelitian menunjukkan bahwa penyesuaian diri anak asuh terhadap lingkungan alamiah menunjukan kategori tinggi, penyesuaian diri terhadap lingkungan sosial menunjukan kategori rendah karena masih banyak anak asuh yang tidak memiliki hubungan baik dengan anak asuh lainnya, pembina dan pegawai/staf, penyesuaian diri terhadap diri sendiri menunjukan kategori rendah karena anak asuh sulit untuk mengontrol emosi dan
\end{abstract}


tidak dapat fokus dalam mengikuti kegiatan di Lembaga Kesejahteraan Sosial Anak (LKSA), penyesuaian diri terhadap ketegangan, konflik dan frustasi yang dialaminya menunjukan kategori sedang.

Kata Kunci:

Penyesuaian Diri, Anak Asuh, Lembaga Kesejahteraan Sosial Anak

\section{PENDAHULUAN}

Indonesia disebut juga dengan Republik Indonesia (RI) atau Negara Kesatuan Republik Indonesia (NKRI) merupakan negara di Asia Tenggara yang dilintasi garis khatulistiwa dan berada di antara daratan benua Asia dan Australia, serta antara Samudera Pasifik dan Samudera Hindia. Indonesia adalah negara kepulauan terbesar di dunia dengan luas wilayah mencapai $1.919 .440 \mathrm{~km}^{2}$ yang terdiri dari 17.504 pulau. Dengan populasi hampir 270 juta jiwa pada tahun 2020, Indonesia adalah negara berpenduduk terbesar keempat di dunia.

$$
\text { Badan Pusat Statistik (BPS) }
$$

memproyeksikan jumlah penduduk Indonesia pada 2020 mencapai 269,6 juta jiwa. Jumlah penduduk laki-laki di Indonesia mencapai 135,34 juta jiwa sedangkan perempuan sebanyak 134,27 juta jiwa. Sementara berdasarkan kelompok usia, Sebanyak 185,22 juta jiwa atau sekitar $68,7 \%$ dari total populasi penduduk Indonesia merupakan usia produktif (usia 15-64 tahun), sementara sebanyak 66,05 juta jiwa atau $24,5 \%$ dari total populasi penduduk Indonesia merupakan usia belum produktif (0-14 tahun), dan sebanyak 18,06 juta jiwa atau $6,7 \%$ dari total populasi penduduk Indonesia merupakan usia sudah tidak produktif (diatas 65 tahun). Angka tersebut berdasarkan proyeksi pertumbuhan penduduk Indonesia tahun 2020 yang dilakukan Badan Perencanaan Pembangunan, Badan Pusat Statistik dan United Pupulation Fund.
Berdasarkan data dari Badan Pusat Statistik (BPS) pada tahun 2020, BPS memproyeksikan bahwa 30,1\% atau 79,5 juta jiwa penduduk Indonesia adalah anak-anak berusia 0-17 tahun dimana sebanyak 39,1 juta jiwa merupakan anak perempuan dan sebanyak 40,4 juta jiwa merupakan anak lakilaki. Diprediksikan proporsi anak di Indonesia pada beberapa kurun waktu ke depan juga tidak akan mengalami perubahan signifikan. Ini artinya hampir satu diantara tiga penduduk Indonesia adalah anak-anak.

Kesejahteraan anak menjadi masalah nasional sehingga menjadi tugas negara untuk menyelesaikannya, sejatinya masalah demikian bukan hanya tugas negara semata tetapi kita pun memiliki kewajiban untuk memperhatikan kesejahteraan mereka dari segala aspek kehidupannya. Salah satu fungsi lembaga kesejahteraan sosial anak membantu adalah masalah sosial anak, Lembaga tersebut difokuskan pada peningkatan kesejahteraan sosial anak seperti anak terlantar, lemahnya ekonomi, hancurnya keluarga serta ditinggal wafat oleh salah satu atau kedua orang tua, merupakan alasan mereka terlantar. Berdasarkan Data Terpadu Kesejahteraan Sosial (DTKS) tercatat hingga 2019 terdapat 106.406 anak di 4864 Lembaga Kesejahteraan Sosial Anak (LKSA)/Panti Asuhan terdaftar di seluruh Indonesia. Oleh karena itu peneliti tertarik untuk fokus meneliti dan memecahkan permasalah anak di Indonesia. Selain konsern pada anak hingga mengambil kajian mengenai anak, peneliti juga melihat 
banyaknya permasalahan anak di Indonesia. Hal tersebut dapat dilihat dalam Permensos No.8 tahun 2012 tentang Pedoman Pendataan dan Pengelolaan Data Penyandang Masalah Kesejahteraan Sosial dan Potensi Sumber Kesejahteraan Sosial saja terdapat 7 permasalahan khusus anak dari 26 permasalahan yang ada, diantaranya: 1) Anak Balita Terlantar, 2) Anak Terlantar, 3) Anak yang Berhadapan dengan Hukum, 4) Anak Jalanan, 5) Anak dengan Kedisabilitasan, 6) Anak yang menjadi Korban Tindak Kekerasan, dan 7) Anak yang Memerlukan Perlindungan Khusus.

Secara umum apa yang dimaksud dengan anak adalah keturunan atau generasi sebagai suatu hasil dari hubungan kelamin atau persetubuhan (sexual intercourse) antara seorang laki-laki dengan seorang perempuan baik dalam ikatan perkawinan maupun diluar perkawinan. maka dapat dinyatakan bahwa anak adalah seseorang yang belum dewasa dan berusia dibawah 18 tahun termasuk yang masih di dalam kandungan.

Pemerintah menyadari pentingnya ketersediaan bermacam indikator anak. Sebagai aset pembangunan, maka pemerintah perlu berinvestasi secara intensif pada kesehatan dan kesejahteraan anak-anak di Indonesia. Bagaimana dengan tumbuh kembang anak terkait dengan kesehatan dan nutrisi yang diperlukan, pendidikan dan kesejahteraan anak, lingkungan tempat anak tumbuh dan berkembang dan faktor-faktor lainnya. Beberapa hal tersebut merupakan penentu masa depan anak. Sangat penting mengetahui sejauh mana indikator-indikator tersebut mencapai kemajuan atau belum. Indikator-indikator yang disajikan dapat menggambarkan lebih akurat tentang kondisi anak di masa sekarang dan membuka peluang yang lebih besar bagi kemajuan bangsa Indonesia di masa akan datang.

Oleh karena itu banyak upaya dari pemerintah maupun Lembaga-lembaga swasta dalam mencapai kesejahteraan sosial bagi anak. Karena pentingnya kesejahteraan sosial anak bagi masa yang akan datang. Sebagai contoh dari Lembaga Kesejahteraan Sosial Anak (LKSA) yang melaksanakan upaya kesejahteraan sosial anak antara lain: 1) Panti Sosial Bina Remaja Taruna Jaya di Jakarta Selatan; 2) Pondok Remaja Inabah XVII Puteri Pesantren Suryalaya di Ciamis; 3) Panti Sosial Asuhan Anak (PSAA) Putra Utama 5 di Jakarta Timur; 4) Panti Asuhan Yatim Piatu Muhammadiyah di Klaten; 5) Panti Sosial Marsudi Putri Antasena di Magelang; dan 6) Panti Asuhan Baiturahmah di Kampar, Riau.

Lembaga Kesejahteraan Sosial Anak (LKSA) yang disebutkan diatas menjadi tempat dilakukannya penelitian dengan bersumber dari hasil penelitian yang sudah dilakukan sebelumnya yang dimana berbagai lembaga yang sudah disebutkan berbeda-beda fungsinya (heterogen) namun secara umum cukup mewakili LKSA di Indonesia. Secara umum bidang pelayanan yang diberikan adalah memberikan pelayanan, bimbingan, dan pengarahan dalam hal pemenuhan kebutuhan fisik, mental dan spiritual maupun sosial bagi anak asuh sehingga mereka memperoleh kesempatan untuk berkembang secara luas, tepat dan memadai bagi perkembangan pribadi anak sesuai dengan prilaku maupun tuntutan agama. Dengan demikian pelayanan yang diberikan oleh lembaga-lembaga tersebut merupakan pelayanan yang bersifat langsung untuk tumbuh kembang anak asuh.

Maksud penyelenggaraan LKSA adalah sebagai usaha untuk meningkatkan 
kesejahteraan sosial anak di Indonnesia dengan memberikan pelayanan pengganti dalam pemenuhan kebutuhan fisik, mental, dan sosial serta untuk menyantuni dan mengasuh anak dari keluarga yang tidak mampu atau terlantar. Sehingga terpenuhinya hak anak yang meliputi hak hidup, tumbuh kembang, perlindungan, dan handal serta proporsional berguna bagi agama, bangsa, dan negara.

Tidaklah mudah bagi seorang anak yang hidup dalam sebuah lingkungan yang baru untuk menyesuaikan dirinya dengan baik, karena pada hakikatnya lingkungan baru bagi beberapa anak merupakan sebuah stimulus yang terkadang mampu menjadi penyebab terjadinya kesulitan dalam menyesuaikan diri. Begitu pula halnya dengan seorang anak asuh panti yang baru mengenal lingkungan panti, dimana lingkungan ini memiliki karakteristik yang berbeda dengan lingkungan sebelumnya seperti lingkungan di keluarga atau lingkungan di jalanan ditambah dengan asal dan latar belakang yang berbeda-beda. Dalam menghadapi lingkungan baru ini, anak membutuhkan kemampuan untuk dapat menyesuaikan diri dengan lingkungan sehingga dengan modal tersebut, seorang anak dapat beraktivitas dalam menjalankan tugastugas di panti dengan baik. Dimana jika penyesuaian diri anak tidak sesuai juga dapat berdampak terhadap tumbuh kembang anak tersebut.

Penyesuaian diri merupakan salah satu persyaratan penting bagi terciptanya kesehatan jiwa dan mental individu. Tinjauan literatur menyebutkan penyesuaian diri menurut James F. Calhoun dan Joan Rose Acocella dalam Alex Sobur (2011: 526) memberikan definisi tentang penyesuaian diri yaitu, "penyesuaian dapat didefinisikan sebagai interaksi yang kontinu dengan diri anda sendiri, dengan orang lain, dengan dunia anda". Dalam kenyataannya banyak individu yang tidak mampu menyesuaikan dirinya, hal ini juga dikaitkan dengan penyesuaian diri anak, tidak jarang dari mereka mengalami kegagalan untuk melakukan penyesuaian diri dengan lingkungan baru ditambah jika lingkungan tersebut berada dalam kondisi yang penuh tekanan.

Berdasarkan uraian tersebut, peneliti merasa tertarik untuk melakukan penelitian di Lembaga Kesejahteraan Sosial Anak (LKSA) yang ada di Indonesia untuk memperoleh gambaran secara empiris dan menggali lebih dalam tentang "Penyesuaian Diri Anak Asuh di Lembaga Kesejahteraan Sosial Anak (LKSA)". Dimana penelitian ini berbeda dari penelitian yang sudah dilakukan sebelumnya yang juga merupakan sumber data penelitian ini, karena penelitian ini meruapakan kompilasi dari penelitian yang dilakukan dari berbagai daerah di Indonesia. Dengan aspek yang diteliti yaitu penyesuaian diri anak asuh terhadap lingkungan alamiah, lingkungan sosial, diri sendiri, dan ketegangan, konflik, serta frustasi yang dialaminya. Adapun yang menjadi perumusan masalah dalam penelitian ini adalah sebagai berikut: 1) Bagaimana karakteristik anak asuh di Lembaga Kesejahteraan Sosial Anak? 2) Bagaimana penyesuaian diri anak asuh terhadap lingkungan alamiah di Lembaga Kesejahteraan Sosial Anak? 3) Bagaimana penyesuaian diri anak asuh terhadap lingkungan sosial di Lembaga Kesejahteraan Sosial Anak? 4) Bagaimana penyesuaian diri anak asuh terhadap diri sendiri di Lembaga Kesejahteraan Sosial Anak? dan 5) Bagaimana penyesuaian diri anak asuh terhadap ketegangan, konflik dan frustasi yang dialaminya di Lembaga Kesejahteraan Sosial Anak? 


\section{METODE PENELITIAN}

Desain Penelitian yang digunakan dalam penelitian ini adalah Analisis Data Sekunder (ADS). Hal ini mengacu pada pendapat Heaton dalam Andrews dkk (2012: 12) merumuskan bahwa Analisis Data Sekunder (ADS), yaitu "secondary data analysis a research strategy which makes use of pre-existing quantitative data or preexisting qualitative data for the purposes of investigating new questions or verifying previous studies. " Jadi, analisis data sekunder, menurut Heaton merupakan suatu strategi penelitian yang memanfaatkan data kuantitatif ataupun kualitatif yang sudah ada untuk menemukan permasalahan baru atau menguji hasil penelitian terdahulu.

Data yang digunakan untuk dianalisis secara garis besar merupakan hasil penelitian mengenai penyesuaian diri dimasing-masing lokasi penelitian yang menjadi sumber data penelitian dan selanjutnya dikategorikan sesuai dengan latar belakang dari setiap LKSA yang berbeda-beda contohnya seperti lembaga anak yang fokus terhadap anak korban penyalahgunaan NAPZA, anak jalanan, anak yang berhadapan dengan hukum, ataupun anak terlantar dan yatim piatu. Dimana dalam penelitian ini akan dianalisi terkait permasalahan anak asuh, kebutuhan anak asuh, dan sistem sumber untuk anak asuh di LKSA sebagai objek penelitian.

Teknik pengumpulan data merupakan langkah yang paling strategis dalam penelitian karena tujuan utama dari penelitian adalah untuk mendapatkan data. Adapun teknik pengumpulan data yang digunakan oleh peneliti dalam penelitian ini adalah Analisis Data Sekunder (ADS) dengan menjadikan skirpsi dan jurnal mengenai penyesuaian diri anak asuh sebagai sumber data penelitian.
Adapun langkah-langkah dalam teknik analisis data sebagai berikut; 1) Reduksi dan kategorisasi data, 2) Mengorganisasikan data, dan 3) Interpretasi.

\section{HASIL PENELITIAN}

Penelitian ini merupakan Analisis Data Sekunder (ADS) sehingga penelitian terdahulu menjadi salah satu sumber data pendukung yang dapat dijadikan acuan ataupun perbandingan oleh peneliti yang berkaitan dengan fokus penelitian yang relatif sama. Penulis mengkaji beberapa penelitian terdahulu yang dijadikan sumber data dalam penulisan skripsi ini yakni sebagai berikut: 1) Penyesuaian Diri Remaja Korban Penyalahguna Narkotika, Psikotropika, dan Zat Adiktif (NAPZA) dalam Mengikuti Rehabilitasi di Pondok Remaja Inabah XVII Puteri Pesantren Suryalaya Kabupaten Ciamis (Tamara Senada Islami, 2018), 2) Penyesuaian Diri Anak Asuh di Lingkungan Panti Sosial Bina Remaja (PSBR) Taruna Jaya I Tebet Jakarta Selatan (Augy Putro Harseno, 2017), 3) Penyesuaian Diri Anak di Panti Sosial Marsudi Putera Antasena Magelang Jawa Tengah (Faizal, Rizalih Manggala, 2017), 4) Penyesuaian Diri Pada Remaja yang Tinggal di Panti Asuhan (Studi Kasus Pada Remaja yang Tinggal di Panti Asuhan Yatim Piatu Muhammadiyah Klaten (Nuqman Rifai, 2015), 5) Kemampuan Penyesuaian Diri Pada Remaja di Panti Sosial Asuhan Anak (PSAA) Putra Utama 5 Duren Sawit Jakarta Timur (Suci Supratiwi, 2007), dan 6) Tingkat Penyesuaian Diri Anak yang Tinggal di Panti Asuhan (Studi Kasus Panti Asuhan Baiturrahmah Desa Rimbo Panjang Km. 17 Kecamatan Tambang Kabupaten Kampar Riau (Pipit Suwita, 2016).

\section{Karakteristik Anak Asuh}


Karakterisik anak asuh dalam penelitian ini adalah anak asuh yang tersebar di enam lokasi berbeda di Indonesia seperti yang sudah di sebutkan diatas. Jumlah anak asuh dalam penelitian ini berjumlah 417 orang yang terdiri dari anak dengan batasan usia 6-21 tahun atau usia sekolah SD, SMP, dan SMA. Adapun komposisi anak asuh berdasarkan lokasi penelitian antara lain:

Tabel 1. Komposisi Anak Asuh Berdasarkan Lokasi

\begin{tabular}{|c|l|r|}
\hline No. & \multicolumn{1}{|c|}{ Lokasi LKSA } & Jumlah Anak \\
\hline 1. & PSBR Taruna Jaya 1 & 110 \\
\hline 2. & $\begin{array}{l}\text { Pondok Remaja Inabah } \\
\text { XVII Puteri Pesantren } \\
\text { Suryalaya Ciamis }\end{array}$ & 32 \\
\hline 3. & PSAA Putra Utama 5 & 105 \\
\hline 4. & $\begin{array}{l}\text { Panti Asuhan Yatim Piatu } \\
\text { Muhammadiyah Klaten }\end{array}$ \\
\hline 5. & PSMP Antasena Magelang & 52 \\
\hline 6. & $\begin{array}{l}\text { Panti Asuhan Baiturahmah } \\
\text { Kampar, Riau }\end{array}$ & 68 \\
\hline & \multicolumn{2}{|c|}{ Jumlah } \\
\hline
\end{tabular}

Karakteristik anak asuh berdasarkan jenis kelamin menunjukan bahwa jumlah keseluruhan anak asuh yang tersebar di enam lokasi penelitian berbeda berjumlah 417 orang dengan jenis kelamin yang paling banyak adalah laki-laki yaitu 232 orang $(55,6 \%)$ yang tersebar di lima lokasi penelitian, karena dapat dilihat bahwa salah satu lokasi penelitian yaitu Pondok Remaja Inabah XVII Puteri Pesantren Suryalaya hanya terdapat anak asuh perempuan. Sedangkan perempuan berjumlah 185 orang $(44,4 \%)$ yang tersebar di lima lokasi penelitian, karena dapat dilihat bahwa salah satu lokasi penelitian yaitu Panti Sosial Marsudi Putra Antasena Magelang hanya terdapat anak asuh laki-laki. Jumlah anak asuh berdasarkan jenis kelamin tersebut didapat dari hasil perhitungan data enam penelitian yang kemudian di distribusikan secara proporsional ke dalam unsur gender yang dibagi menjadi dua yaitu laki-laki dan perempuan. Adapun rinciannya adalah sebagai berikut:

Tabel 2 Jumlah Anak Asuh Berdasarkan Jenis Kelamin

\begin{tabular}{|c|l|r|r|}
\hline No. & \multicolumn{1}{|c|}{ Lokasi LKSA } & \multicolumn{1}{c|}{ L } & \multicolumn{1}{c|}{ P } \\
\hline 1. & PSBR Taruna Jaya 1 & 71 & 39 \\
\hline 2. & $\begin{array}{l}\text { Pondok Remaja Inabah } \\
\text { XVII Puteri Pesantren } \\
\text { Suryalaya Ciamis }\end{array}$ & 0 & 32 \\
\hline 3. & PSAA Putra Utama 5 & 52 & 53 \\
\hline 4. & $\begin{array}{l}\text { Panti Asuhan Yatim Piatu } \\
\text { Muhammadiyah Klaten }\end{array}$ & 27 & 23 \\
\hline 5. & PSMP Antasena Magelang & 52 & 0 \\
\hline 6. & $\begin{array}{l}\text { Panti Asuhan Baiturahmah } \\
\text { Kampar, Riau }\end{array}$ & 30 & 38 \\
\hline \multicolumn{2}{|c|}{ Jumlah } & $\mathbf{2 3 2}$ & $\mathbf{1 8 5}$ \\
\hline
\end{tabular}

Sumber: Data Hasil Penelitian Terdahulu

Karakteristik anak asuh berdasarkan kelompok usia dalam penelitian ini dikategorikan menjadi dua fase, antara lain yang pertama adalah fase anak sekolah, 6-15 tahun (masa belajar atau masa sekolah rendah), dan kedua adalah fase remaja, 16-21 tahun (masa peralihan dari anak menjadi dewasa yang terdiri dari masa remaja awal, tengah dan akhir). karakteristik anak asuh di enam Lembaga Kesejahteraan Sosial Anak (LKSA) yang dijadikan lokasi penelitian, berdasarkan kelompok usia terbanyak berada pada kelompok usia periode 16-20 tahun yaitu sebanyak $50 \%$ dari jumlah keseluruhan, periode ini dapat juga dikatakan sebagai fase remaja (masa peralihan dari anak ke dewasa). sedangkan yang paling sedikit berada pada kelompok usia periode 6-10 tahun atau hanya sebanyak $2 \%$ dari jumlah keseluruhan, periode ini merupakan fase anak sekolah (masa belajar atau masa sekolah rendah). Adapun rinciannya adalah sebagai berikut: 
Tabel 3 Jumlah Anak Asuh Berdasarkan Kelompok Usia

\begin{tabular}{|c|l|r|}
\hline No. & $\begin{array}{c}\text { Kelompok } \\
\text { Usia }\end{array}$ & $\begin{array}{c}\text { Jumlah Anak dalam } \\
\text { persentase (\%) }\end{array}$ \\
\hline 1. & $6-10$ tahun & 2 \\
\hline 2. & $11-15$ tahun & 40 \\
\hline 3. & $16-20$ tahun & 50 \\
\hline 4. & 20 tahun $>$ & 8 \\
\hline \multicolumn{2}{|c|}{ Jumlah } & $\mathbf{1 0 0}$ \\
\hline
\end{tabular}

Sumber: Data Hasil Penelitian Terdahulu

Karakteristik anak asuh berdasarkan tingkat pendidikan yang berada di enam lokasi penelitian terdalulu terdapat pada tingkat SMP (Sekolah Menengah Pertama) atau sederajat yaitu 189 orang, jumlah tersebut hampir mencapai setengah dari jumlah keseluruhan anak asuh di enam lokasi penelitian terdahulu. Adapun rinciannya adalah sebagai berikut:

Tabel 4 Jumlah Anak Asuh Berdasarkan Tingkat Pendidikan

\begin{tabular}{|c|l|r|}
\hline No. & \multicolumn{1}{|c|}{ Tingkat Pendidikan } & $\begin{array}{c}\text { Jumlah } \\
\text { Anak }\end{array}$ \\
\hline 1. & Tidak Sekolah & 4 \\
\hline 2. & TK & 16 \\
\hline 3. & SD/Sederajat & 63 \\
\hline 4. & SMP/MTS/Sederajat & 189 \\
\hline 5. & SMA/SMK/MA/Sederajat & 142 \\
\hline 6. & Perguruan Tinggi & 3 \\
\hline & Jumlah & $\mathbf{4 1 7}$ \\
\hline
\end{tabular}

Sumber: Data Hasil Penelitian Terdahulu

\section{Penyesuaian Diri Terhadap Lingkungan Alamiah}

Lingkungan alamiah merupakan alam luar dan semua yang melingkupi individu yang vital dan alami, seperti makanan, pakaian, tempat tinggal, dan peralatan yang ada di Panti Asuhan atau Lembaga Kesejahteraan Sosial Anak (LKSA). Setiap individu memiliki kemampuan penyesuaian diri terhadap lingkungan alamiah yang berbeda-beda.
Penyesuaian lingkungan alamiah adalah kemampuan seseorang untuk dapat menerima keadaan dan situasinya sekarang selain dirinya seperti sandang, pangan, dan papan yang merupakan kebutuhan primer bagi setiap individu. Individu dapat menjalani kehidupan yang seimbang jika dapat menyesuaikan diri dengan lingkungan alamiahnya. Sebaliknya, apabila individu tidak dapat menyesuaikan diri dengan lingkungan alamiahnya maka akan terjadi ketidakseimbangan dalam kehidupannya.

Penelitian terdahulu yang menjadi sumber pendukung yang dapat dijadikan acuan ataupun perbandingan oleh peneliti yang berkaitan dengan penyesuaian diri terhadap lingkungan alamiah dapat digambarkan pada penelitian yang berlokasi di Pondok Remaja Inabah XVII Putri Pesantren Suryalaya Kabupaten Ciamis dan Panti Sosial Marsudi Putra Antasena Magelang Jawa Tengah.

Dari hasil penelitian yang berlokasi di Pondok Remaja Inabah XVII Puteri Pesantren Suryalaya Kabupaten Ciamis dan Panti Sosial Marsudi Putra Antasena Magelang Jawa Tengah menunjukan bahwa jika dilihat dari aspek penyesuaian diri terhadap lingkungan alamiah dalam mengikuti kegiatan di LKSA, maka dapat disimpulkan bahwa aspek penyesuaian diri terhadap lingkungan alamiah menunjukan jika mayoritas anak asuh cukup baik dalam menyesuaikan dirinya. Hal ini terbukti dari kegiatan yang dijalankan oleh beberapa anak asuh dapat menyesuaikan diri terhadap lingkungan alamiah meskipun ada juga beberapa dari anak asuh yang belum dapat menyesuaikan diri terhadap lingkungan alamiah dengan optimal dalam mengikuti kegiatan kegiatan yang dilaksanakan di LKSA atau Panti. 


\section{Penyesuaian Diri Terhadap Lingkungan Sosial}

Penyesuaian lingkungan sosial adalah kemampuan seseorang untuk dapat menjalin hubungan baik dengan orang lain di sekitarnya. Hubungan-hubungan tersebut mencakup hubungan dengan masyarakat di sekitar tempat tinggalnya, keluarga, sekolah, teman atau masyarakat luas secara umum. Individu yang dapat menyesuaikan dengan lingkungan sosialnya akan menurut sejumlah aturan, hukum, norma, adat dan nilai-nilai yang sesuai dengan lingkungannya. Sebaliknya, apabila individu tidak dapat menyesuaikan diri dengan lingkungan sosialnya ia tidak akan mengikuti aturan yang berlaku di lingkungan tersebut sehingga hubungan dengan lingkungan sekitarnya tidak dapat terjalin dengan baik.

Penelitian terdahulu yang menjadi sumber pendukung yang dapat dijadikan acuan ataupun perbandingan oleh peneliti yang berkaitan dengan penyesuaian diri terhadap lingkungan sosial adalah penelitian yang berlokasi di Pondok Remaja Inabah XVII Putri Pesantren Suryalaya Kabupaten Ciamis, Panti Sosial Bina Remaja Taruna Jaya I Tebet Jakarta Selatan, Panti Sosial Yatim Piatu Muhammadiyah Klaten, dan Panti Sosial Marsudi Putra Antasena Magelang Jawa Tengah.

Dari hasil penelitian yang berlokasi di Pondok Remaja Inabah XVII Puteri Pesantren Suryalaya Kabupaten Ciamis, Panti Sosial Bina Remaja Taruna Jaya I Tebet Jakarta Selatan, Panti Sosial Yatim Piatu Muhammadiyah Klaten, dan Panti Sosial Marsudi Putra Antasena Magelang Jawa Tengah. menunjukkan bahwa jika dilihat dari aspek penyesuaian diri terhadap lingkungan sosial, maka dapat disimpulkan bawah anak asuh kurang baik dalam menyesuaikan dirinya.
Hal ini terbukti dari kegiatan yang dilakukan secara bersama-sama belum maksimal dikarenakan masih adanya pertengkaran, tidak saling menghargai, dan memiliki hubungan yang kurang baik antara sesama anak asuh maupun dengan Pembina.

\section{Penyesuaian Diri Terhadap Diri Sendiri}

Diri sendiri (The Self), tempat individu menguasai dirinya. Mengatur bagaimana dia bergerak dan melakukan aktivitas, bagaimana manusia berinteraksi dengan lingkungan, bagaimana manusia menguasai dan mengendalikan keinginan mereka dalam memilih keputusan yang ada di Panti Asuhan atau Lembaga Kesejahteraan Sosial Anak (LKSA). Setiap individu memiliki kemampuan penyesuaian diri terhadap diri sendiri yang berbeda-beda.

Penyesuaian diri sendiri adalah kemampuan seseorang untuk menerima dirinya sendiri demi tercapai hubungan yang harmonis antara dirinya dengan lingkungan sekitarnya. Penyesuaian diri sendiri berhubungan dengan konflik, tekanan dan keadaan dalam diri individu, baik keadaan fisik maupun keadaan psikis. Individu yang dapat menyesuaikan diri dengan baik akan merasa aman, bahagia, memiliki sikap positif dan pandangan positif. Sebaliknya, apabila individu mengalami penyesuaian yang buruk, kehidupan kejiwaannya ditandai oleh kegoncangan emosi atau kecemasan yang menyertai rasa bersalah, cemas, tidak puasa, kurang dan keluhan terhadap nasib yang dialaminya. Hal tersebut dapat berdampak tidak hanya pada dirinya sendiri namun juga lingkungan sekitarnya.

Penelitian terdahulu yang menjadi sumber pendukung yang dapat dijadikan acuan ataupun perbandingan oleh peneliti 
yang berkaitan dengan penyesuaian diri terhadap diri sendiri adalah penelitian yang berlokasi di Pondok Remaja Inabah XVII Putri Pesantren Suryalaya Kabupaten Ciamis, Panti Sosial Bina Remaja Taruna Jaya I Tebet Jakarta Selatan, Panti Asuhan Yatim Piatu Muhammadiyah Klaten dan Panti Sosial Marsudi Putra Antasena Magelang Jawa Tengah.

Dari hasil penelitian yang digambarkan oleh LKSA yang berlokasi di Pondok Remaja Inabah XVII Puteri Pesantren Suryalaya Kabupaten Ciamis, Panti Sosial Bina Remaja Taruna Jaya I Tebet Jakarta Selatan, Panti Asuhan Yatim Piatu Muhammadiyah Klaten dan Panti Sosial Marsudi Putra Antasena Magelang Jawa Tengah menunjukkan bahwa jika dilihat dari aspek penyesuaian diri terhadap diri sendiri di LKSA atau Panti dapat dikatakan kurang baik. Pada aspek penyesuaian diri terhadap diri sendiri dikatakan belum maksimal karena mayoritas anak selalu mudah marah dan tersinggung kepada orang-orang disekitarnya, kemudian mereka mengalami perasaan cemas yaitu sulit untuk tidur, tidak dapat fokus, tenang, mengalami ketakutan dan kepanikan selama di LKSA atau Panti, lalu banyak anak yang memiliki keinginan untuk lari dari LKSA atau Panti yang mereka tempati. Sehingga dapat disimpulkan dari hasil penelitian yang ada bahwa penyesuaian diri anak asuh terhadap dirinya sendiri.

\section{Penyesuaian Diri Terhadap Ketegangan, Konflik, dan Frustasi yang Dialami}

Kemampuan mengatasi ketegangan, konflik dan frustrasi, yaitu kemampuan individu untuk memenuhi kebutuhan dirinya tanpa terganggu oleh emosinya, kemudian kemampuan memahami orang lain dan keragamannya, kemampuan mengambil keputusan dan dapat mengatasi suatu permasalahan dengan tenang yang ada di Panti Asuhan atau Lembaga Kesejahteraan Sosial Anak (LKSA). Setiap individu memiliki kemampuan penyesuaian diri terhadap ketegangan, konflik, dan frustasi yang dialami dengan berbeda-beda., peranan sosial, dukungan sosial, organisasi keluarga, pola komunikasi, dan diskriminasi. Berikut ini merupaka jawaban responden aspek kondisi sosial.

Penelitian terdahulu yang menjadi sumber pendukung yang dapat dijadikan acuan ataupun perbandingan oleh peneliti yang berkaitan dengan penyesuaian diri terhadap terhadap ketegangan, konflik, dan frustasi yang dialami adalah penelitian yang berlokasi di Panti Sosial Asuhan Anak (PSAA) Putra Utama 5 Duren Sawit Jakarta Timur, Panti Asuhan Baiturrahmah Desa Rimbo Panjang Km.17 Kecamatan Tambang Kabupaten Kampar, Prov. Riau dan Panti Sosial Yatim Piatu Muhammadiyah Klaten.

Dari hasil penelitian yang digambarkan oleh LKSA yang berlokasi di Panti Sosial Asuhan Anak (PSAA) Putra Utama 5 Duren Sawit Jakarta Timur, Panti Asuhan Baiturrahmah Desa Rimbo Panjang Km.17 Kecamatan Tambang Kabupaten Kampar, Prov. Riau dan Panti Sosial Yatim Piatu Muhammadiyah Klaten menunjukkan bahwa jika dilihat dari aspek penyesuaian diri terhadap ketegangan, konflik, dan frustasi yang dialami anak asuh di LKSA atau Panti dapat dikatakan cukup baik. Hal tersebut menunjukan kemampuan penyesuaian diri anak asuh yang meskipun selalu mengalami ketegangan, konflik dan frustasi teteapi anakanak tersebut selalu dapat mengatasinya. Dapat disimpulkan bahwa dalam hal ini anak masih cukup baik dalam menyesuaikan diri, 
hal ini merupakan salah satu ciri good adjustment.

\section{PEMBAHASAN HASIL PENELITIAN}

Panti Asuhan atau Lembaga

Kesejahteraan Sosial Anak (LKSA) menurut Kementerian Sosial Republik Indonesia (2004: 4), yaitu suatu lembaga usaha kesejahteraan sosial anak yang mempunyai tanggung jawab untuk memberikan pelayanan kesejahteraan sosial pada anak terlantar dengan melaksanakan penyantunan dan pengentasan anak terlantar, memberikan pelayanan pengganti orang tua/wali anak dalam memenuhi kebutuhan fisik, mental dan sosial kepada anak asuh sehingga memperoleh kesempatan yang luas, tepat dan memadai bagi pengembangan kepribadianya sesuai dengan yang diharapkan sebagai bagian dari generasi penerus cita-cita bangsa dan sebagai insan yang akan turut serta aktif dalam bidang pembangunan nasional. Dalam hal ini penulis melakukan analisis terhadap penelitian yang telah dilakukan sebelumnya di LKSA atau Panti asuhan seperti yang sudah disebutkan diatas mengenai penyesuaian diri anak asuhnya.

\section{Aspek Penyesuaian Diri Terhadap Lingkungan Alamiah}

Sebagaimana yang dinyatakan oleh Alex Sobur (2011) bahwa penjelasan mengenai penyesuaian diri terhadap lingkungan alamiah pada pokoknya adalah alam luar dan semua yang melingkupi individu yang vital dan alami, seperti pakaian, tempat tinggal, makanan dan sebagainya. Dalam hal ini dapat dilihat dari penelitian penyesuaian diri anak asuh yang berlokasi di Pondok Remaja Inabah XVII Putri Pesantren Suryalaya Kabupaten Ciamis dan Panti Sosial Marsudi Putra Antasena Magelang Jawa Tengah. Dapat disimpulkan bahwa hasil penelitian pada aspek lingkungan alamiah yaitu tinggi, dimana anak asuh dapat melakukan kegiatankegiatan di panti seperti memenuhi kebutuhan sandang, pangan dan papan di Pondok Remaja Inabah XVII Putri Pesantren Suryalaya Kabupaten Ciamis dan Panti Sosial Marsudi Putra Antasena Magelang Jawa Tengah.

\section{Aspek Penyesuaian Diri Terhadap Lingkungan Sosial}

Sebagaimana yang dinyatakan oleh Enung Fatmimah (2008: 207) bahwa penjelasan mengenai penyesuaian diri terhadap lingkungan sosial pada pokoknya adalah kemampuan individu dalam berinteraksi dengan lingkungan masyarakat tempat individu tersebut hidup. Dalam hal ini individu diharapkan dapat menciptakan hubungan-hubungan sosial yang baik dengan orang-orang yang berada di lingkungan sekitarnya. Hal terpenting yang harus dilakukan individu dalam penyesuaian sosial adalah kemauan dan niat untuk mematuhi segala aturan, nilai dan norma sosial yang ada di lingkungan masyarakatnya. Dalam hal ini dapat dilihat dari penelitian penyesuaian diri anak asuh yang berlokasi di Pondok Remaja Inabah XVII Putri Pesantren Suryalaya Kabupaten Ciamis, Panti Sosial Bina Remaja Taruna Jaya I Tebet Jakarta Selatan, Panti Sosial Yatim Piatu Muhammadiyah Klaten, dan Panti Sosial Marsudi Putra Antasena Magelang Jawa Tengah. Dapat disimpulkan bahwa hasil penelitian pada aspek lingkungan sosial yaitu rendah, hal ini karena anak asuh sulit untuk menyesuaikan diri dengan beradaptasi dengan anak binaan atau anak asuh lain, pembina, pegawai di panti, karena anak asuh sering bertengkar dengan anak lainnya sehingga membuat mereka tidak menyukai kegitan yang melibatkan kelompok, 
tidak memiliki rasa kepedulian terhadap sesame anak asuh, saling mengolok sesama anak asuh dan tidak memiliki hubungan yang baik dengan anak binaan lain. Anak asuh merasa tidak berhubungan baik dengan pembina karena masih kurangnya interaksi yang baik sehingga anak tidak nyaman dekat dengan Pembina.

\section{Aspek Penyesuaian Diri Terhadap Diri Sendiri}

Sebagaimana yang dinyatakan oleh Enung Fatmimah (2008: 207) bahwa penjelasan mengenai penyesuaian diri terhadap diri sendiri atau pribadi pada diri terkait kemampuan individu dalam memahami dirinya sendiri baik dari kelebihan maupun kekurangannya. Penyesuaian pribadi juga erat kaitannya dengan kondisi emosional. Apabila kondisi emosional individu tersebut stabil dan tidak mengalami goncangan, maka dapat dikatakan potensi pencapaian penyesuaian pribadi akan berhasil. Sebaliknya, jika kondisi emosional tidak stabil dan mengalami goncangan, hal inilah yang dapat menghambat penyesuaian pribadi. Dalam hal ini dapat dilihat dari penelitian penyesuaian diri anak asuh yang berlokasi di Pondok Remaja Inabah XVII Putri Pesantren Suryalaya Kabupaten Ciamis, Panti Sosial Bina Remaja Taruna Jaya I Tebet Jakarta Selatan, Panti Asuhan Yatim Piatu Muhammadiyah Klaten dan Panti Sosial Marsudi Putra Antasena Magelang Jawa Tengah. Dapat disimpulkan bahwa hasil penelitian pada aspek diri sendiri responden yaitu rendah karena adanya rasa benci dengan sesama anak binaan lain ataupun dengan pembina, lalu anak asuh tidak dapat fokus dan tenang dalam mengikuti rehabilitasi, kelas keterampinan ataupun kegiatan yang ada di panti.

\section{Aspek Penyesuaian Diri Terhadap Ketegangan, Konflik, dan Frustasi yang Dialami}

Sebagaimana yang dinyatakan oleh Schneiders (2008) bahwa penjelasan mengenai penyesuaian diri terhadap ketegangan, konflik, dan frustasi yang dialami pada pokoknya adalah kemampuan mengatasi ketegangan, konflik dan frustrasi, yaitu kemampuan individu untuk memenuhi kebutuhan dirinya tanpa terganggu oleh emosinya, kemudian kemampuan memahami orang lain dan keragamannya, kemampuan mengambil keputusan dan dapat mengatasi suatu permasalahan dengan tenang. Dalam hal ini dapat dilihat dari penelitian penyesuaian diri anak asuh yang berlokasi di Panti Sosial Asuhan Anak (PSAA) Putra Utama 5 Duren Sawit Jakarta Timur, Panti Asuhan Baiturrahmah Desa Rimbo Panjang Km.17 Kecamatan Tambang Kabupaten Kampar, Prov. Riau dan Panti Sosial Yatim Piatu Muhammadiyah Klaten. Dapat disimpulkan bahwa hasil penelitian keseluruhanya dapat dilihat semua anak asuh dapat menerima keadaanya yang sekarang dan kenyataan latar belakang keluarganya tanpa ada rasa malu atau minder. Proses penyesuaian diri juga berjalan dengan baik ketika sedang belajar menyesuaikan diri dengan lingkungan panti asuhan selalu dibantu oleh pengasuh dan teman-teman yang berada di dalam panti asuhan. Dari segi emosi anak asuh mampu untuk mengontrol emosi dan mengendalikan emosi seperti selalu mencurahkan hatinya kepada teman-temanya jika sedang mengalami masalah atau problem. Masalah utama yang menjadi hambatan penyesuain diri anak asuh adalah sikap pengasuh yang menurut mereka adalah sangat keras.

\section{Analisis Masalah}


Analisis masalah dilakukan guna mengetahui kemungkinan-kemungkinan yang terjadi akibat penyesuaian diri anak asuh yang dapat dikatakan belum cukup baik, analisis masalah adalah langkah awal sebelum seseorang dapat mengatasi masalahnya yang dalam hal ini anak asuh di bantu oleh pekerja sosial seperti yang dinyatakan oleh Siporin dalam Adi Fahrudin (2012: 61), mendefinisikan pekerjaan sosial sebagai berikut: "Pekerjaan sosial didefinisikan sebagai suatu metoda institusi sosial untuk membantu orang mencegah dan memecahkan masalah mereka serta untuk memperbaiki dan meningkatkan keberfungsian sosial mereka". Dalam hal ini penulis menganalisis mengenai masalah terkait penyesuaian diri anak asuh di Lembaga Kesejahteraan Sosial Anak (LKSA) atau Panti Asuhan.

Penyesuaian diri merupakan suatu masalah bagi seseorang khususnya orangorang yang berada pada lingkungan baru dan banyak perbedaan seperti menurut Fahmi dalam Alex Sobur (2011: 526) mengemukakan definisi penyesuaian diri adalah "Suatu proses dinamik terus menerus yang bertujuan untuk mengubah kelakuan guna mendapatkan hubungan yang lebih serasi antara diri dan lingkungannya". Dalam hal ini seperti yang dialami anak asuh saat harus menyesuaikan diri terhadap lingkungan alamiah, lingkungan sosial, diri sendiri, dan ketegangan, konflik, serta frustasi yang dialami di Panti Asuhan atau Lembaga Kesejahteraan Sosial Anak (LKSA) yang saat ini menjadi lingkungan dimana ia tinggal. Berikut ini pembahasan analisa masalah dari masing-masing aspek sebagai berikut:

a. Penyesuaian diri terhadap lingkungan alamiah

Penyesuaian diri terhadap lingkungan alamiah yang dimaksud dalam penelitian ini yaitu penyesuaian diri terhadap makanan, pakaian dan tempat tinggal yang ada di Panti Asuhan atau LKSA. Penyesuaian diri anak asuh dapat dikatakan positif apabila responden sudah mampu menyesuaikan diri dengan semua hal yang melingkupi vital dan alami seperti makanan, pakaian dan lain sebagainya. Apabila anak asuh belum bisa menerima semua yang melingkupinya baik yang vital maupun alami berarti anak belum mampu untuk melakukan penyesuaian diri yang positif.

Berdasarkan hasil penelitian di lapangan dengan menggunakan kuisoner, observasi, wawancara, dan studi dokumentasi yang selanjutnya di analisis melalui enam penelitian dari lokasi yang berbeda, dapat disimpulkan bahwa anak asuh belum optimal menyesuaikan diri terhadap lingkungan alamiah yang meliputi makanan, pakaian dan tempat tinggal karena beberapa dari anak asuh menunjukan bahwa mereka tidak nyaman tinggal satu kamar dengan anak binaan atau anak asuh lainnya. dan adanya kebosanan yang dialami karena sarana prasarana yang kurang membuat anak senang dalam menjalankan aktivitas di Panti Asuhan atau LKSA.

b. Penyesuaian diri terhadap lingkungan sosial

Penyesuaian diri terhadap lingkungan sosial yang dimaksud dalam penelitian yaitu penyesuian diri terhadap orang-orang yang ada di lingkungan Panti Asuhan atau LKSA seperti teman sesama anak asuh, pembina di panti, instruktur, pemdamping anak, dan pegawai atau staf panti lainnya. Penyesuaian diri terhadap lingkungan sosial mampu dikatakan positif apabila mampu untuk melakukan interaksi yang positif dengan teman sesama anak asuh, pembina di panti, instruktur, pemdamping anak, dan pegawai 
atau staf panti, mampu menghargai orang lain, mampu bersikap terbuka, dan saling membantu satu sama lain.

Berdasarkan hasil penelitian di lapangan dengan menggunakan kuisoner, observasi, wawancara, dan studi dokumentasi yang selanjutnya di analisis melalui enam spenelitian dari lokasi yang berbeda menunjukkan bahwa penyesuaian diri terhadap lingkungan sosial berada pada kategori rendah. Hubungan sosial yang terjalin di lingkungan panti kurang terjalin dengan baik dikarenakan beberapa anak asuh masih malu dan takut untuk berinteraksi dengan anak asuh lainnya dan adapun beberapa anak yang memiliki hubungan tidak baik dikarenakan mereka sering bertengkar seperti saling mengolok bahkan berkata kasar sehingga menyebabkan mereka jarang mengobrol dan saling berkubu antara individu dengan individu lain.

c. Penyesuaian diri terhadap diri sendiri

Penyesuaian diri terhadap dirinya sendiri yang dimaksud dalam penelitian ini yaitu bagaimana anak asuh mengatur, menguasai, dan mengendalikan keinginan serta tuntutannya yang tidak sesuai dengan kondisi anak asuh di panti karena anak harus terikat dengan aturan-aturan yang berlaku di Panti Asuhan atau LKSA. Penyesuaian diri yang positif berarti anak asuh harus mampu mengatur, menguasai, dan mengendalikan keinginannya serta tuntutan apabila keinginan tersebut tidak patut atau tidak masuk akal, tidak menunjukan adanya ketegangan emosional yang berlebihan, memiliki pertimbangan yang rasional dalam pengarahan diri, tidak menunjukkan adanya mekanisme pertahanan diri yang salah, tidak menunjukkan adanya frustasi pribadi, serta mampu bersikap realistik dan objektif. Apabila anak asuh belum mampu untuk melakukan penyesuaian diri yang positif maka dimungkinkan mengakibatkan penyesuaian diri yang salah.

Berdasarkan hasil penelitian di lapangan dengan menggunakan kuisoner, observasi, wawancara, dan studi dokumentasi yang selanjutnya di analisis melalui enam penelitian dari lokasi yang berbeda dapat disimpulkan bahwa penyesuaian diri terhadap diri sendiri berada pada kategori rendah. Hal ini menunjukkan bahwa penerimaan terhadap dirinya sendiri di panti kurang dapat menyesuaikan diri hal ini akan berdampak negatif dalam kehidupannya di Panti Asuhan atau LKSA.

d. Penyesuaian diri terhadap ketegangan, konflik, dan frustasi yang dialami

Penyesuaian diri terhadap ketegangan, konflik, dan frustasi yang dialami yang dimaksud dalam penelitian ini yaitu kemampuan mengatasi ketegangan, konflik dan frustrasi antara lain kemampuan individu untuk memenuhi kebutuhan dirinya tanpa terganggu oleh emosinya, kemudian kemampuan memahami orang lain dan keragamannya, kemampuan mengambil keputusan dan dapat mengatasi suatu permasalahan dengan tenang di Panti Asuhan atau LKSA.

\section{Analisis Kebutuhan}

Siporin dalam Adi Fahrudin (2012) menyatakan bahwa "Pekerjaan sosial didefinisikan sebagai metode kelembagaan sosial untuk membantu orang untuk mencegah dan memecahkan masalah-masalah sosial mereka, untuk memulihkan dan meningkatkan keberfungsian mereka". Kebutuhan dan masalah adalah dua hal yang saling berhubungan dan berkesinambungan. Jika masalah sosial membutuhkan pemecahan, maka kebutuhan sosial memerlukan 
pemenuhan. Berdasarkan hasil penelitian mengenai penyesuaian diri anak asuh di Panti Asuhan atau Lembaga Kesejahteraan Sosial Anak (LKSA), dapat diperoleh gambaran dari keempat aspek yaitu penyesuaian diri terhadap lingkungan alamiah, penyesuaian diri terhadap lingkungan sosial, penyesuaian diri terhadap diri sendiri dan penyesuaian diri terhadap ketegangan, konflik, dan frustasi yang dialami. Menurut hasil penelitian yang diperoleh dari keempat aspek penyesuaian diri di enam lokasi penelitian dapat dikatakan bahwa yang paling rendah yaitu penyesuaian diri terhadap lingkungan sosial dan penyesuaian diri terhadap diri sendiri. Oleh karena itu berdasarkan analisis masalah maka diperoleh kebutuhan yang sesuai untuk meningkatkan penyesuaian diri terhadap lingkungan sosial dan penyesuaian diri terhadap diri sendiri di Panti Asuhan atau Lembaga Kesejahteraan Sosial Anak (LKSA) sebagai berikut:

1. Peningkatan relasi anak asuh dengan anak binaan atau anak asuh lainnya, pembina, pendamping anak, dan pegawai (staf panti).

2. Peningkatan kemampuan anak dalam mematuhi peraturan yang ditetapkan oleh pihak Panti Asuhan atau Lembaga Kesejahteraan Sosial Anak (LKSA).

3. Peningkatan rasa aman dan nyaman anak asuh dalam mengikuti rehabilitasi, pengembangan keterampilan, maupun pengasuhan di Panti Asuhan atau Lembaga Kesejahteraan Sosial Anak (LKSA).

\section{Analisis Sistem Sumber}

Menurut Allen Pincus dan Anne Minahan dalam Dwi Heru Sukoco (2011), Sumber adalah segala sesuatu yang memiliki nilai, sesuatu yang berada dalam simpanan atau telah tersedia, dimana orang dapat menggali dan menggunakannya sebagai alat sehingga berfungsi untuk memenuhi kebutuhan atau memecahkan masalah. Sehingga dapat disimpulkan bahwa sistem sumber berfungsi untuk dasar pembuatan rencana pemenuhan kebutuhan bagi anak asuh di Panti Asuhan atau Lembaga Kesejahteraan Sosial Anak (LKSA) yang memiliki permasalahan dengan penyesuaian dirinya. Menurut Allen Pincus dan Anne Minahan sistem sumber dibagi menjadi 3 (tiga) diantaranya yaitu:

\section{a. Sistem sumber informal atau alamiah}

Sistem sumber informal adalah sumber yang dapat memberikan bantuan berupa dukungan emosional, afeksi, nasihat dan informasi, serta pelayanan-pelayanan konkrit lainnya. Sistem sumber ini dapat diakses karena adanya hubungan kekerabatan. Sistem sumber informal yang dapat diakses untuk penanganan masalah adalah berasal dari keluarga, teman, dan lain-lain. Orang terdekat yang dapat memberikan dukungan berupa pemberian motivasi kepada anak agar termotivasi untuk meningkatkan penyesuaian dirinya.

b. Sistem sumber formal

Sistem sumber formal adalah sumber yang dapat memberikan bantuan atau pelayanan langsung terutama kepada para anggotanya. Sumber formal yang dapat dimanfaatkan adalah pihak Panti Asuhan atau Lembaga Kesejahteraan Sosial Anak (LKSA) dalam hal ini antara lain: 1) Panti Sosial Bina Remaja Taruna Jaya di Jakarta Selatan, 2) Pondok Remaja Inabah XVII Puteri Pesantren Suryalaya di Ciamis, 3) Panti Sosial Asuhan Anak (PSAA) Putra Utama 5 di Jakarta Timur, 4) Panti Asuhan Yatim Piatu Muhammadiyah di Klaten, 5) Panti Sosial Marsudi Putra Antasena di Magelang, dan 6) Panti Asuhan Baiturahmah di Kampar, Riau. 
c. Sistem sumber kemasyarakatan

Sistem ini mungkin menyediakan sumber daya secara langsung untuk anggotaanggotanya atau membantu anak asuh menegosiasikan dengan sistem sosial yang berbeda. Adapun sistem kemasyarakatan yang bisa diakses adalah Dinas Sosial di masingmasing lokasi Lembaga Kesejahteraan Sosial Anak (LKSA) untuk mendukung pelaksanaan Program Peningkatan Penyesuaian Diri Anak Asuh melalui Kelompok Sosialisasi (Socialization Group) di Panti Asuhan atau LKSA.

\section{KESIMPULAN}

Berdasarkan hasil penelitian dapat dikatakan bahwa penyesuaian diri anak asuh di Lembaga Kesejahteraan Sosial Anak (LKSA) atau Panti Asuhan dalam kategori rendah atau kurang untuk menyesuaikan diri. Penyesuaian diri terhadap lingkungan alamiah berada pada kategori "tinggi" mampu menyesuaiakan diri. Hal ini dapat dilihat pada aspek makanan, pakaian, dan tempat tinggal yang ada di LKSA atau Panti Asuhan. Begitu pula penyesuaian diri anak asuh terhadap lingkungan sosial menunjukkan bahwa mereka belum bisa maksimal dalam menyesuaikan diri dengan lingkungan sosial.

Penyesuaian diri terhadap lingkungan sosial berada pada kategori "rendah", pada aspek penyesuaian diri terhadap lingkungan sosial dapat dikatakan yang paling rendah bila dibandingkan dengan aspek yang lain. Hal ini ditunjukkan dengan adanya pertengkaran serta saling berprasangka buruk dengan teman satu panti sehingga interaksi yang terjalin menjadi kurang maksimal. Selain itu, terdapat anak asuh yang belum mentaati peraturan yang ada di LKSA atau Panti Asuhan. Adapun penyesuaian diri terhadap dirinya sendiri (the self) berada pada kategori "rendah".
Berdasarkan hasil penelitian di lapangan dengan menggunakan kuisoner, observasi, wawancara, dan studi dokumentasi yang selanjutnya di analisis melalui enam penelitian dari lokasi yang berbeda dapat disimpulkan bahwa penyesuaian diri terhadap diri sendiri berada pada kategori rendah. Hal ini menunjukkan bahwa penerimaan terhadap dirinya sendiri di panti kurang dapat menyesuaikan diri hal ini akan berdampak negatif dalam kehidupannya di Panti Asuhan atau LKSA.

Penyesuaian diri terhadap ketegangan, konflik, dan frustasi yang dialami yang dimaksud dalam penelitian ini yaitu kemampuan mengatasi ketegangan, konflik dan frustrasi antara lain kemampuan individu untuk memenuhi kebutuhan dirinya tanpa terganggu oleh emosinya, kemudian kemampuan memahami orang lain dan keragamannya, kemampuan mengambil keputusan dan dapat mengatasi suatu permasalahan dengan tenang di Panti Asuhan atau LKSA. Apabila anak asuh belum mampu untuk melakukan penyesuaian diri yang positif maka dimungkinkan mengakibatkan penyesuaian diri yang salah.

Penelitian penyesuaian diri anak asuh terhadap lingkungan alamiah, sosial, diri sendiri, maupun ketegangan, konflik, dan frustasi yang dialami dapat disimpulkan bahwa dalam menyesuaikan diri di LKSA atau Panti Asuhan berada pada kategori "rendah". Namun dari keempat aspek yang telah dipaparkan tersebut, aspek yang memiliki penyesuaian diri terendah yaitu penyesuaian diri terhadap lingkungan sosial dan aspek diri sendiri. Oleh karena itu, untuk mengatasi permasalahan tersebut, penulis merekomendasikan beberapa kebutuhan yang diperlukan dalam mengatasi permasalahan tersebut antara lain peningkatan relasi anak 
asuh terhadap lingkungan sosial, peningkatan kemampuan anak asuh dalam mematuhi peraturan yang ditetapkan oleh panti, serta peningkatan rasa aman dan nyaman responden di Lembaga Kesejahteraan Sosial Anak (LKSA) atau Panti Asuhan.

\section{DAFTAR PUSTAKA}

Adi Fahrudin. (2012). Pengantar Kesejahteraan Sosial. Bandung: PT Refika Aditama.

Alex Sobur. (2011). Psikologi Umum. Bandung: Pustaka Setia.

Andrews, Lorraine, et.al. (2012). Classic Grounded Theory to Analyze Secondary Data: Reality and Reflections (The Grounded Theory Review). Volume 11, Issue 1.

Arif Gosita. (2004). Masalah Perlindungan Anak. Jakarta: Bhuana Ilmu Populer.

Burhan Bungin. (2012). Analisis Data Penelitian Kualitatif. Jakarta: Rajawali Pers.

Butler, I. \& Roberts, G. (2004). Social Work with Children and Families: Getting into practice 2nd ed. London, Jessica Kingsley Publisher.

Desmita. (2009). Psikologi Perkembangan Peserta Didik. Bandung: PT Remaja Rosdakarya.

Dwi Heru Sukoco. (2011). Profesi Pekerjaan Sosial dan Proses Pertolongannya. Bandung: Kopma STKS.

Ellya Susilowati, Dkk. (2015). Pekerjaan Sosial pada Program Kesejahteraan Sosial Anak (PKSA) di Kota Bandung. Dalam ejournal Kemsos, Volume 5, No.1, 2015. Diakses pada tanggal 18 Agustus 2019.

Herry Koswara, Dkk. (2011). Garvin: Groupwork. Bandung: STKS Bandung.

Hurlock, E. B. (2003). Psikologi Perkembangan. Suatu Pendekatan
Sepanjang Rentang Kehidupan. Alih bahasa: Istiwidayati \& Soedjarwo. Edisi Kelima. Jakarta: Erlanga.

Ikawati, dkk. (2007). Pengkajian Model Pemberdayaan Lembaga Perlindungan Anak Dalam Pelayanan Kesejahteraan Anak. Balai Besar Penelitian dan Pengembangan Pelayanan Kesejahteraan Sosial.

Isbandi Rukminto Adi. (2015). Kesejahteraan Sosial. Jakarta: PT Raja Grafindo Persada. Jejak Pendidikan (Portal Pendidikan Indonesia). (2016). Pengertian Fungsi dan Tujuan Lembaga Kesejahteraan Sosial Anak (LKSA). Diakses pada hari Rabu, 14 Agustus 2019 pukul 14.30 WIB. Dari https://www.jejakpendidikan.com/2016/11 /pengertian-fungsi-dan-tujuan-

lembaga.html.

Kementerian Perencanaan Pembangunan Nasional (Bappenas). (2018). Jumlah Penduduk Indonesia Menurut Kelompok Umur dan Jenis Kelamin (2019). Diakses pada hari Rabu, 14 Agustus 2019 pukul 13.45 WIB. Dari https://databoks.katadata.co.id/datapublish /2019/01/04/jumlah-penduduk-indonesia2019-mencapai-267-juta-jiwa.

Lusi Nuryanti. (2008). Psikologi Anak. Jakarta: PT Indeks.

Moleong, L. (2011). Metodologi Penelitian Kualitatif Edisi Revisi. Bandung: PT. Remaja Rosdakarya Offset.

Pipit Suwita. (2016). Tingkat Penyesuaian Diri Anak yang Tinggal di Panti Asuhan (Studi Kasus Panti Asuhan Baiturrahmah Desa Rimbo Panjang Km. 17 Kecamatan Tambang Kabupaten Kampar Provinsi Riau. Jurnal Universitas Riau. JOM FISIP Vol. 3 No. 2.

Schneider, L R \& Lester, Lori. (2010). Advokasi Pekerja Sosial. Sebuah 
Kerangka untuk Bergerak (Terjemahan).

Bandung: STKS Bandung.

Soetarso. (2011). Praktek Pekerjaan Sosial.

Cetakan Pertama. Bandung: STKS

Bandung.

Sugiyono. (2017). Metode Penelitian

Kuantitatif, Kualitatif, dan $R \& D$.

Bandung: Alfabeta.

Tatang M. Amirin. (2015). Metode Penelitian Sekunder (Analisis Data

Sekunder). Yogyakarta: Universitas

Negeri Yogyakatya (Tatang M.

Amirin Blog)

Undang-Undang No 39 Tahun 1999 tentang Hak Asasi Manusia.

Undang-undang No. 35 Tahun 2014 Tentang Perubahan Atas Undang-Undang Nomor 23 tahun 2002 tentang Perlindungan Anak.

Viva Budy Kusnandar. (2020). Inilah Proyeksi Jumlah Penduduk Indonesia 2020. Diakses pada hari Kamis, 7 Mei 2020 pukul 14.10 WIB. Dari https://databoks.katadata.co.id/datapublis h/2020/01/02/inilah-proyeksi-jumlahpenduduk-indonesia-2020. 